\title{
MASYARAKAT ISLAM INDONESIA PADA ABAD MODERN DAN KONTEMPORER
}

\author{
Saiul Anah \\ Dosen LB FTK UINSA Surabaya \\ Bundanashrul@gmail.com
}

\begin{abstract}
Abstrac: The expression of the Indonesian Islamic Community is the response of Muslims to the development of modernity, so that the big of the Islamic revival is divided into three groups, namely Islamic revivalisme, Islamic reformisme and Islamic fundamentalisme. Revival Islam gave to several movement groups, including: patienting Islam, traditionalist Islam, orthodox Islam, Neo-revivalisme, and conservative Islam. While reformist Islam gave to several movements, such as: modernist Islam, liberal Islam, substantial Islam, and Neo-modernists. while, fundamentalist Islam gave to radical Islam, militant Islam and even terrorisme. Methodologically the understanding of Islam, the modern and contemporary Islamic thought movements, as stated by loualy sufi consists of two, namely groups that use and apply the classical Islamic system and groups that use the paradigm of modern Western epistemology in total or with a process of integration between modern scholarship. West with the treasures of Islamic scholarship. Based on this, it is worth mentioning that the diversity of Indonesian Muslims as a national treasure must be knitted so that interreligious harmony is created as a characteristic of the true character of the Indonesian nation.
\end{abstract}

Keyword : Kebhinekaan, Islamic thinking, Indonesia

\section{Pendahuluan}

Gerakan keislaman atau kebangkitan Islam dimulai sejak Islam bersentuhan dengan Barat melalui kolonialisasi dan imperialisasi wilayah kekuasaan Islam ${ }^{1}$ dan ini merupakan awal dari abad modern di dunia Islam, atau dalam pandangan ${ }^{2}$ merupakan masa kebangkitan Islam. Islam dihadapkan dengan kondisi zaman yang begitu progresif, berada di luar bayangan umat Islam sebelumnya, Barat datang dengan seperangkat temuan-temuan canggih dalam bentuk sains dan teknologi, sistem sosial yang begitu apik, semuanya merupakan cermin atau ciri dari modernisme yang berkembang di Barat. Napoleon Banoparte (1798-1801) yang datang ke Mesir misalnya datang dengan segenap perangkat modernisme, seperti disertakannya para ilmuwan,

\footnotetext{
${ }^{1}$ Amstrong, Karen. (2001). Berperang Demi Tuhan.terj., Sartio Wahono dkk. Bandung: Mizan. Halm 45.

${ }^{2}$ Harun Nasution. (1986). Akal dan Wahyu dalam Islam. cet. II. Jakarta: UI- Press. Halm. 88.
} 
perpustakaan, literatur Eropa modern, laboratorium ilmiah, serta alat-cetak dengan huruf Latin, Yunani, dan Arab. ${ }^{3}$

Dari kondisi ini maka dimulailah apa yang dinamakan dengan gerakan kebangkitan Islam, yang dalam pandangan ${ }^{4}$ melihat bahwa respons Islam terhadap Barat justru melahirkan Muslim modernis dalam pandangan yang modernis pula. Terkait dengan ini maka tokoh-tokoh yang lahir adalah mereka yang telah berinteraksi dengan budaya luar, terutama budaya pemikiran dan pendidikan Barat, sehingga pandangan keislaman yang mereka ajukan lebih kontekstual dan demokratis. Dalam pandangan mereka transformasi budaya modern Barat yang progresif ke wilayah Islam sudah tidak terbendung, dan agar Islam relevan dengan kondisi zaman yang dihadapi maka harus ada reinterpretasi ulang yang lebih edukatif, kontekstual, progresif dan akomodatif, atau rethinking Islam ${ }^{5}$ Rethinking Islam yang ditawarkan Mohammed Arkoun bertujuan untuk menggunakan nalar kritis bebas rasional untuk mengelaborasi dengan khazanah-khazanah keilmuan Islam. ${ }^{6}$ Maka dalam bahasa Islam upaya tersebut dinamakan ijtihad yang kontinyu dan intensif dalam segala aspek, baik fiqh, kalam, dan sebagainya.

Melihat respons umat Islam terhadap modernisme dan modernisasi Barat dilakukan dengan tiga bentuk; pertama apologetik, kedua identifikatif, dan ketiga afirmatif ${ }^{7}$. Secara garis besar, sebagai sebuah dampak dari kehadiran bangsa Barat di dunia Islam telah melahirkan tiga kelompok Islam yang berskala luas di seluruh belahan dunia Islam, yakni, Islam revivalisme, Islam reformis, dan Islam fundamentalisme ${ }^{8}$.

Kehadiran Agama dan Ekspresi Keberagamaan Agama hadir dalam diri

\footnotetext{
${ }^{3}$ Harun Nasution. (1986). ....., Halm. 95

${ }^{4}$ Fachry Ali. (1996). Golongan Agama dan Etika Kekuasaan: Keharusan Demokratisasi dalam Islam Indonesia. cet. I. Surabaya: Risalah Gusti. Halm. 316.

5. Arkoun,Mohamed (ed). (1999). Membongkar Wacana Hegemoni dalam Islam dan Postmodernis. terj. Jaohari dkk. cet. I. Surabaya: al- Fikri. Halm. 28.

${ }^{6}$ Gerakan pembaharuan ini dimulai sejak Islam bersentuhan dengan dunia Barat melalui kolonialisasi dan imperialisasi wilayah kekuasaan Islam, dan ini merupakan awal dari abad modern di dunia Islam (Armstrong, 2003: 169-192).

${ }^{7}$.Azyumardi Azra. (1996). Pergolakan Politik Islam; Dari Fundamentalisme,Modernisme hingga Posmodernisme. cet. I. Jakarta: Paramadina. Halm. 89.

8 _. (1999b). Islam Reformis; Dinamika Intelektual dan Gerakan. cet. I. Jakarta: PT Grapindo Persada. Halm. 56.
} 
manusia sepanjang sejarah eksistensinya di muka bumi, agama juga hadir berdasarkan kebutuhan yang amat manusiawi, paling tidak dari segi emosional manusia itu sendiri ${ }^{9}$. Atas sifatnya yang sejalan dengan sifat-sifat manusia inilah kemudian agama diyakini dan dijadikan sebagai landasan hidup worldview, karena agama dalam posisinya yang sakral dianggap sebagai blue print Tuhan yang diformulasikan untuk selanjutnya dijadikan rujukan untuk sebuah visi baru dan koheren yang mengintegrasikan kondisi baru yang dihadapi umat dengan mengintegrasikan kondisi baru yang dihadapi umat dengan unsur-unsur tradisi muslim yang masih ada, atau integrasi antara kemajuan budaya modern Barat menyelesaikan segala permasalahan hidup ${ }^{10}$. Dalam konteks yang demikian, agama sejatinya diturunkan dan dianut oleh masyarakat dikarenakan memiliki sebab dan tujuan-tujuan tertentu, dan yang paling fundamen dari sebab dan tujuan tersebut adalah harapan tempat menyandarkan kedamaian, kebaikan, dan keselamatan di dunia dan akhirat ${ }^{11}$.

Agama juga telah dijadikan sebagai ideologi dalam menciptakan dan menggerakkan spirit motivasional bagi manusia sebagai bentuk mengaktualisasi diri dalam kehidupan, dan sebagai gerakan revolusioner untuk pembebasan diri dari tirani, hegemoni, dan ketidakadilan sosial politik, budaya serta ekonomi ${ }^{12}$. Atas dasar sifat dan fungsi agama yang demikianlah masyarakat memeluk agama, di samping karena beragama atau bertuhan sudah menjadi fitrah manusia Dengan karakteristik dan peran agama yang demikian, tidak heran jika terdapat pandangan yang mengatakan bahwa jika kita mau mengetahui peradaban dunia atau suatu kelompok masyarakat dan negara, maka yang harus dibuka adalah pintu jendela agama. ${ }^{13}$ Dalam pandangan yang demikian maka kesimpulannya adalah, bahwa peradaban terbentuk berdasarkan keyakinan dan nilai religiusitas masyarakat, sehingga mempelajari kebudayaan atau peradaban tidak akan mencapai hasil maksimal jika penelitian tentang agama diabaikan. Dalam teori

\footnotetext{
9. Azyumardi Azra. (1996).,......, Halm 10.

10. Jalaluddin Rahmat. (1998). Islam Alternatif: Ceramah-Ceramah di Kampus. cet. 2. Bandung: Ghanesa. Halm 89.

11. Jalaluddin Rahmat. (1998),.........., Halm 90.

12. Fachry Ali. (1996). Golongan Agama dan Etika Kekuasaan: Keharusan Demokratisasi dalam Islam Indonesia. cet. I. Surabaya: Risalah Gusti. Halm 107.

${ }^{13}$ Al-Bana, Gamal.(2006). Pluralitas dalam Masyarakat Islam. terj., Tim Mata Air Publishing. Jakarta: Mata Air Publishing.
} 
budaya yang dikembangkan Clifford Geertz terlihat bahwa agama menjadi fondasi bagi terbentuknya suatu kultur dan tradisi dalam masyarakat, yakni manifestasi agama dalam budaya. Jika dilihat dari fakta historis berupa data-data arkeologis, karya-karya seni dan bangunan-bangunan sejarah, maka teori tersebut terbukti dengan sendirinya sebagai sebuah kebenaran sosial-kultural dan historis, seperti bangunan-bangunan candi yang masih berdiri kokoh di Jawa, seperti candi Borobudur, candi Prambanan, candi Loro Jonggrang, dan sebagainya. Dalam konteks Indonesia, semua itu merefleksikan kuatnya agama dalam kehidupan masyarakat Jawa, dan candi merupakan simbol dari peradaban yang dibangun di atas fondasi agama, yakni Hindu dan Budha. Jika kita melangkah ke wilayah dunia lain juga akan ditemukan bukti-bukti historis yang sama, seperti Masjid Tajmahal di India, Piramida di Mesir, dan sebagaianya. Semua itu merefleksikan sebuah peradaban keyakinan manusia atas agamanya. ${ }^{14}$

\section{Pembahasan}

Agama sebagai sistem nilai yang universal, memiliki daya tarik yang menarik untuk ditawarkan kepada manusia, sebagaimana yang dikatakan Joachim Wach bahwa agama memiliki tiga bentuk dalam pengungkapan nilai universalnya, yakni, belief system ${ }^{15}$, system of workship ${ }^{16}$, system of social relation ${ }^{17}$. Sedangkan dalam tataran nilai religiusitas, agama memiliki lima dimensi, yaitu; dimensi belief (ideologi), dimensi practice (praktik agama), dimensi feeling (pengalaman), dimensi knowledge (pengetahuan), dan dimensi effect (konsekuensi) ${ }^{18}$.

Di samping itu, agama merupakan wilayah atau bagian dari fenomena hidup yang susah untuk dipahami, sebab agama yang sama akan berubah bentuk pemahaman pada wilayah yang berbeda, tergantung dari setting sosial-kultural masyarakat. Sebab itu kita menemukan beberapa pendefinisian agama oleh para

\footnotetext{
14 Barton, Greg. (1999).Gagasan Islam Liberal Di Indonesia: Pemikiran Neo- Modernisme Nurcholis Madjid, Djohan Effendi, Ahmad Wahib, dan Abdurrahman Wahid. terj., Nanang Tahqiq. Jakarta: UIN Press.

${ }^{15}$ Pengungkapan teoretik yang terwujud sebagai sistem kepercayaan.

${ }^{16}$ Sistem penyembahan

17 Sistem hubungan masyarakat.

18 . Lawrence, Bruce B. (2004). Islam Tidak Tunggal: Melepaskan Islam Dari Kekerasan.terj., Harimukti Bagus Oka. cet. II. Jakarta: Serambi. Halm 78.
} 
pakar, sosiolog, dan antropolog, seperti Clifford Geertz ${ }^{19}$. dengan merumuskan agama sebagai: (1) Sebuah sistem simbol yang berfungsi untuk (2) Membangun perasaan dan motivasi yang penuh kekuatan, pervasif dan tanpa akhir dalam diri manusia dengan (3) Merumuskan konsep mengenai tatanan umum eksistensi dan (4) Membungkus konsepsi-konsepsi tersebut dengan suatu aura faktualitas sehingga (5) Perasaan dan motivasi di atas menjadi realistis.

William James mendefinisikan agama sebagai ${ }^{20}:$ “... perasaan, tindakan, dan pengalaman manusia secara individual saat berada dalam perenungan atau kontemplasi saat sendiri sejauh tindakan menyendiri tersebut membawanya ke dalam kondisi yang dianggap sakral”.Sementara Joachim Wach (1892- 1967) menerapkan beberapa persyaratan mutlak untuk sampai kepada pemahaman yang benar dan utuh terhadap agama yang diteliti, di antaranya adalah syarat intelektual, kondisi emosional yang cukup, kemauan yang keras dan pengalaman yang memadai Masih banyak lagi tokoh yang memberikan gambaran tentang apa itu agama dan bagaimana memahami agama. Dari pendefinisian agama tersebut tampak bahwa agama seakan-akan menjadi sebuah daya sakral bagi manusia yang dimanifestasikan ke dalam pola hidup sehari-hari ${ }^{21}$.

Deskripsi di atas memberikan sebuah acuan dan pemahaman kepada manusia bahwa semua itu merefleksikan bentuk dari manifestasi agama dalam kehidupan sosial-kultural masyarakat. Yang menjadi pertanyaan kemudian adalah bagaimana masyarakat mempersepsikan agama ke dalam dirinya, terinternalisasi menjadi sebuah keyakinan mutlak, dan mampu diterjemahkan ke dalam kehidupan sehari- hari sebagai sebuah worldview dalam memahami, mempersepsi, dan menjalankan kompleksitas hidup di dunia yang profan dan ambigu ini? Sebagaimana yang diulas di atas, telah terdapat perhatian para sosiolog dan antropolog terhadap upaya penelitian untuk memahami agama. Paling tidak kesimpulan sementara yang bisa kita ambil adalah, bahwa pengambilan dan penentuan sikap keberagamaan tidak lepas dari upaya

\footnotetext{
${ }^{20}$ Hanafi,Hasan. (2003). Aku Bagian Dari Fundamentalsime Islam. terj., Kamran As'ad Irsady Mufliha Wijayanti. cet. I. Yogyakarta: Islamika. Halm. 87.

${ }^{21}$. Arkoun,Mohamed (ed). (1999). Membongkar Wacana Hegemoni dalam Islam dan Postmodernis. terj. Jaohari dkk. cet. I. Surabaya: al- Fikri. Halm. 119.
} 
hermetisisme $^{22}$ atau interpretasi terhadap agama ${ }^{23}$. Proses hermetisasi inilah yang akan melahirkan bentuk dan warna agama dalam diri manusia. Namun, upaya hermetisasi ini tidak lepas dari keterpengaruhan seseorang atas kultur, pendidikan, ekonomi, politik, dan kepentingan-kepentingan hidup yang akan dicapai. Sehingga perbedaan kondisi kultur, pendidikan, dan tingkat intelektualitas seseorang akan melahirkan perbedaan bentuk pemahaman dan ekspresi religiusitasnya.

Masalah tersebut paling tidak diungkapkan oleh Mukti Ali bahwa: (a) persoalan dan pengalaman keagamaan bersifat subjektif dan individualistik. Tiap orang mengartikan agama sesuai dengan pengalaman keagamaannya sendiri, (b) karena dimensi kesakralannya, tak ada orang yang begitu bersemangat dan emosional selain membicarakan agama, dan (c) konsepsi tentang agama akan sangat dipengaruhi oleh latar belakang (backround), disiplin ilmu, dan tujuan orang yang memberikan pengertian tentang agama. Islam sebagai Hermenetik ditemukan dari Yunani, yakni pada Hermes atau Nabi Idris dalam Islam, yang mencoba menyebarkan ajaran Tuhan dengan upaya penerjemahan ajaran agama atau bahasa Tuhan ke dalam bahasa masyarakat agar mudah dipahami dan diyakini ${ }^{24}$.

Ekspresi Islam yang ditampilkan oleh umat Islam Indonesia inilah yang akan dikaji dalam tulisan ini, sebuah perkembangan tipologis peta pemikiran keislaman di Indonesia. Semua kelompok dan aliran pemikiran Islam tersebut hadir sebagai respons terhadap proses globalisasi dan modernisasi di Indonesia $^{25}$. Gerakan pemikiran tersebut terlihat baik dalam pemikiran individu, kelompok maupun organisasi keislaman. Dalam sejarah perkembangan teologi di Indonesia terjadi dan dipengaruhi oleh konteks situasi dan kondisi historis tertentu yang dihadapi kaum muslim Indonesia, yang mana untuk kemudian merangsang nalar intelektualitas para cendikiawan muslim untuk memberikan respons- respons tertentu, yang mana respons tersebut mengarah pada gerakan

\footnotetext{
22. Keyakinan Beragama.

23. Pandangan teoretis terhadap sesuatu

${ }^{24}$. Arkoun,Mohamed (ed). (1999). Membongkar Wacana Hegemoni dalam Islam dan Postmodernis. terj. Jaohari dkk. cet. I. Surabaya: al- Fikri. Halm. 87-88.

${ }^{25}$. Arkoun,Mohamed (ed). (1999). Membongkar Wacana Hegemoni dalam Islam dan Postmodernis. terj. Jaohari dkk. cet. I. Surabaya: al- Fikri. Halm. 121.
} 
pembaruan $^{26}$.

Corak Kebhinekaan Umat Islam Indonesia: Upaya Menemukan Karakter Bangsa ada beberapa corak kebhinekaan keberagamaan masyarakat Islam Indonesia yang dapat penulis elaborasikan dalam artikel ini. Teori yang mengacu pada konsekuensi atau kepastian yang mengarah pada dialektika sinergis antara diri dengan lingkungan ${ }^{27}$.

Pertama: Islam Aktual. Islam Aktual merupakan sebuah gerakan yang mencoba membangun suatu tindakan aktif religius dalam menyikapi permasalahan hidup. Islam aktual mencoba merintis kartu reiligius pada umat untuk mengaktualisasikan prinsip-prinsip dan nilai-nilai normatif doktrinal Islam yang terkandung dalam al-Qur'an dan al-Sunnah, bahkan dalam khazanah intelektual Islam yang ada. Islam aktual berusaha untuk melakukan empirisasi atas ajaran Islam dalam kehidupan yang riil dan dalam beragam bentuk kehidupan yang kompleks. Hal ini sesuai dengan makna actual tersebut, yakni keadaan yang sebenarnya atau sesungguhnya ${ }^{28}$.

Dari sini kita dapat mengambil sebuah identitas dari Islam aktual, yakni sebuah gerakan yang mengedepankan pengamalan atau action agama dalam kehidupan empirik, sehingga kebenaran Islam tidak hanya bersifat skripturalis belaka, tapi mampu terinternalisasi dalam pribadi yang menjadi spirit to action dalam kehidupan nyata. Gerakan pembangunan manusia dan masyarakat yang religius, mandiri, dan maju. Hal ini sesuai dengan makna pembangunan manusia jika dikaji secara sosiologis, yakni suatu proses perubahan sosial masyarakat dari suatu keadaan tertentu ke suatu keadaan yang lebih baik dari segala segi ${ }^{29}$.

Gagasan-gagasan Islam aktual yang diarahkan pada pembangunan sosial umat Islam dapat ditemukan dalam pemikiran Jalaluddin Rahmat dengan bukunya "Islam Aktual", di mana ia membahas bagaimana gambaran kondisi Indonesia dan umat Islam yang berada dalam proses pembangunan dan

\footnotetext{
${ }^{26}$. Arkoun,Mohamed (ed). (1999). Membongkar Wacana Hegemoni dalam Islam dan Postmodernis. terj. Jaohari dkk. cet. I. Surabaya: al- Fikri. Halm. 123.

27. Zaim Uchrowi. (1989). Refleksi Pembaharuan Pemikiran Islam: 70 Tahun Harun Nasution.Jakarta: Panitia Penerbit Buku dan Seminar 70 Tahun Harun Nasution dan Lembaga Studi Agama dan Fils. Halm. 116.

${ }^{28}$. Rahman, Fazlur. (1982). Islam. Chicago: The University of Chicago Press.) Halm. 77.

${ }^{29}$ Syari'ati,Ali. (1995).Islam Mazhab Pemikiran dan Aksi. terj., M. S. Nasrulloh dan Afip Muhammad. Halm 67.
} 
modernisasi. Tema- tema permasalahan yang diangkat dalam tulisan Jalaluddin Rahmat cukup aktual, seperti apa itu pembangunan, apa itu organsiasi-organisasi sosial non-agama dan organiasasi keagamaan, apa itu masjid, dan lain sebagainya ${ }^{30}$.

Agama dalam pandangan Kang Jalal akan berperan tergantung pada pemeluknya, bergantung pada peranan yang kita berikan, dan bergantung pada bagaimana kita memandang agama ${ }^{31}$. Cara pandang ini sama dengan yang diungkapkan Ali Syari'ati bahwa suatu agama akan menjadi penting dan bermanfaat-- bukan karena agama itu sendiri, melainkan tergantung pada kualitas pikiran dan intelektualitas para pemeluknya.Jika pemeluknya berpikiran dangkal dan tekstual- skripturalis, maka agama tersebut akan menjadi sempit dan tidak bernilai universal, melainkan akan menjadi agama yang kering nilai, dan pemeluknya akan menjadi dogmatis, konservatif, ekslusif, fundamentalisradikal, dan militan.Namun, jika pemeluknya kritis, berwawasan luas, edukatif serta progresif, maka agama akan menjadi lebih bernilai universal, modern, dan responsif ${ }^{32}$

Kedua: Islam Fundamentalis. Jika dilihat secara geneologis historis, fundamentalsime untuk pertama kali lahir di Amerika sekitar abad ke-19 dan permulaan abad ke-20 pada berbagai gerakan keagamaan sekte kristen Protestan $^{33}$. Fundamentalisme Kristen AS hadir sebagai reaksi terhadap gerakan modernisme Amerika yang sekuler. Namun, para tokoh Kristen berjuang untuk menyelaraskan ajaran agama dengan kemajuan ilmu pengetahuan, evolusionisme, dan liberalisme. Kaum fundamentalis tetap berpegang teguh pada lima ajaran mutlak Kristen, yakni: 1) Injil tidak dapat salah, 2) Ketuhanan Yesus Kristus, 3) Yesus lahir dari Perawan Maria, 4) Penebusan dosa, dan 5) Kebangkitan kembali Yesus ke dunia secara fisik ${ }^{34}$.

\footnotetext{
30. Zaim Uchrowi. (1989). Refleksi Pembaharuan Pemikiran Islam: 70 Tahun Harun Nasution.Jakarta: Panitia Penerbit Buku dan Seminar 70 Tahun Harun Nasution dan Lembaga Studi Agama dan Fils. Halm. 120.

${ }^{31}$. Ayzumardi azra. (1999b). Islam Reformis; Dinamika Intelektual dan Gerakan. cet. I. Jakarta: PT Grapindo Persada. Halm 109.

32. Syari'ati,Ali. (1995).Islam Mazhab Pemikiran dan Aksi. terj., M. S. Nasrulloh dan Afip Muhammad. Halm 38.

33. Arkoun,Mohamed (ed). (1999). Membongkar Wacana Hegemoni dalam Islam dan Postmodernis. terj. Jaohari dkk. cet. I. Surabaya: al- Fikri. Halm. 90-91.

34. Ayzumardi azra. (1999b). Islam Reformis; Dinamika Intelektual dan Gerakan. cet. I. Jakarta: PT
} 
Kajian selama ini menunjukkan bahwa pelabelan fundamentalisme pada kelompok Islam berdasarkan kesamaan ciri, baik dalam prinsip dan praktiknya, seperti yang diungkapkan oleh Ibrahim Abu Bakar. melihat terdapat beberapa kesamaan antara fundamentalsime Kristen dengan fundamentalisme Islam, di antaranya: 1) penafisran yang literalis terhadap kitab suci, 2) fundamentalisme mirip dengan sikap fanatisme, ekslusivisme, radikalisme, intolaran, dan militan, 3) fundamentalisme menekankan pada penolakan terhadap modernism, liberalisme, dan humanisme, dan 4) kaum fundamentalisme melihat orang di luar dirinya sebagai yang sesat dan kelompok merekalah yang paling benar dalam menafsirkan agama ${ }^{35}$.

Di kalangan umat Islam sendiri cenderung tidak mau menggunakan istilah fundamentalisme, seperti Yusuf Qardhawi memakai istilah Sahwah Islamiyah, ${ }^{36}$ dengan istilah Islamawiyah, ${ }^{37}$ dengan istilah al-Usuliyyah Islamiyyah. Sedangkan yang melatarbelakangi lahirnya fundamentalisme Islam hampir sama dengan fundamentalisme Kristen, yakni penolakan atas gerakan modernisme- sekulerisme di negara Islam, karena dipandang bertentangan dengan doktrin Islam. Jadi, fundamentalisme Islam lahir untuk membendung permasalahan internal yang diakibatkan oleh kelompok Islam sendiri yang berusaha mengembangkan budaya modernisme sekulerisme Barat $^{38}$.

Sebagian lagi melihat fundamentalisme dari aspek rigid dan literalis dalam memahami agama. Seperti, Allan Taylor melihat fundamentalisme Islam sebagai kelompok yang melakukan pendekatan konservatif dalam melakukan reformasi keagamaan, bercorak literalis, dan lebih menekankan gerakan puritanisasi ajaran agama. Sementara itu, Bannerman melihat kaum fundamentalis sebagai kelompok ortodoks yang bercorak rigid dan ta'ashub yang bertujuan untuk menegakkan konsep-konsep keagamaan dari abad klasik. Daniel Pipes melihat fundamentalis sebagai kelompok yang meyakini syariah

Grapindo Persada. Halm 105.

35 Very Verdiansyah. (2004). Islam Emansipatoris: Menafsir Agama untuk Praksis Pembebasan.cet. I.Jakarta: P3M. Halm 66.

36. Arkoun,Mohamed (ed). (1999). Membongkar Wacana Hegemoni dalam Islam dan Postmodernis. terj. Jaohari dkk. cet. I. Surabaya: al- Fikri. Halm. 90-91.

37 Amstrong, Karen. (2001). Berperang Demi Tuhan.terj., Sartio Wahono dkk. Bandung: Mizan. Halm 107.

${ }^{38}$ Very Verdiansyah. (2004). Islam Emansipatoris: Menafsir Agama untuk Praksis Pembebasan.cet.

I.Jakarta: P3M. Halm 76. 
sebagai peraturan yang abadi sepanjang zaman tanpa melakukan reinterpretasi untuk menyelesaikannya dengan perkembangan zaman, sehingga kaum fundamentalis sebagai kaum legalis yang konservatif. Bassam Tibi mengartikan fundamentalis sebagai kelompok yang menolak segala sesuatu yang baru dalam kehidupan sosial selain dari apa yang sudah tersedia dalam doktrin agama.

Dari paradigma pemahaman yang rigid dan literalis tersebut, kaum fundamentalisme Islam menganggap Islam sebagai agama yang total, sehingga tidak perlu lagi memasukkan unsur-unsur luar Islam atau Barat untuk menyelesaikan permasalahan umat Islam. Yang perlu dilakukan adalah menerapkan hukum- hukum Islam menjadi sebuah sistem nilai yang universal dalam hidup, baik dalam masyarakat maupun negara ${ }^{39}$.

Ketiga: Islam Emansipatoris. Islam emansipatoris atau Islam untuk pembebasan bisa dikatakan sebagai sebuah gerakan yang muncul untuk mengatasi kesenjangan antaragama yang hanya dilihat sebagai jalinan teks belaka, namun tidak mampu menjangkau realitas sosial yang ada. Islam emansipatoris terkait dengan nalar kritis Islam yang pernah ada, terutama yang beraliran kiri, itulah sebabnya dikatakan sebagai jaringan Islam emansipatoris atau jaringan tafsir emansipatoris atau Islam kritis ${ }^{40}$. Titik tolak dari Islam emansipatoris adalah problem kemanusiaan, dan teks dilihat sebagai subordinat terhadap pesan moral atau etika atau spiritual, dan tidak dipahami sebagai hukum atau undang- undang melainkan sebagai sinaran pembebasan ${ }^{41}$.

Di sini Islam emansipatoris membongkar teks untuk aksi, sehingga dalam tataran praktis hal-hal yang menjadi target pembebasannya adalah: 1) bagaimana mendefinisikan secara adil apa yang dipahami sebagai problem kemanusiaan, 2) bagaimana memperlakukan teks dalam tahap refleksi kritis. Di sini teks diperlakukan untuk mengasah nurani dalam melihat problem kemanusiaan karena teks bukan satu-satunya rujukan dalam melakukan refleksi kritis, 3) bagaimana teks diperlakukan sebagai sumber kritik. Di sini

\footnotetext{
39. Zaim Uchrowi. (1989). Refleksi Pembaharuan Pemikiran Islam: 70 Tahun Harun Nasution.Jakarta: Panitia Penerbit Buku dan Seminar 70 Tahun Harun Nasution dan Lembaga Studi Agama dan Fils. Halm. 118.

${ }^{40}$ Amstrong, Karen. (2001). Berperang Demi Tuhan.terj., Sartio Wahono dkk. Bandung: Mizan. Halm 87.

${ }^{41}$ Ayzumardi azra. (1999b). Islam Reformis; Dinamika Intelektual dan Gerakan. cet. I. Jakarta: PT Grapindo Persada. Halm 113.
} 
membutuhkan metode pemahaman yang mungkin akan berbeda dengan metode konvensional, dan 4) karena teks bukan satu-satunya alat, maka cara apa lagi yang akan dipakai untuk melakukan pembebasan dan pencerahan ${ }^{42}$. Salah satu caranya adalah dengan memperlakukan teks secara lebih ringan dan mendekonstruksinya, yaitu dengan mengabaikan teks dan tidak terlalu mengagungkannya dalam pembahasan ${ }^{43}$.

Islam emansipatoris lahir untuk memberikan warna yang praktis dari Islam untuk penyelesaian problem sosial dan keagamaan manusia. Paling tidak ada tiga kelompok keislaman yang dinilai oleh Islam emansipatoris sebagai yang gagal memainkan peran sebagai agenda pembebasan, yakni; pertama, Islam skripturalis, dilihat sebagai kelompok yang mendasarkan diri pada teks, titik awal dan akhir adalah teks. Kedua, Islam ideologis, Islam yang tidak berangkat dari teks dan tidak pula berakhir pada teks, melainkan dari pilihan kebenaran dan idenya sendiri yang diideologikan. Teks hanya dijadikan sebagai legitimasi dan justifikasi atas apa yang diinginkan. Ketiga, Islam modernis yang hanya melakukan pendalilan terhadap realitas kemodernan atas nama agama ${ }^{44}$.

Terkait dengan studi agama ini, Islam emansipatoris melakukan tiga bentuk; pertama, agama dilihat sebagai realitas sosial. Di sini agama terkadang dilihat sebagai produk sejarah, sebagaimana agama juga membentuk sejarah. Hal ini dilihat dengan alasan bahwa pesan-pesan agama merupakan pesan sosial dan sejarah, sehingga terjadilah akulturasi antara agama dan realitas. Kedua, kritik wacana agama. Ketiga, melakukan reinterpretasi atas doktrin-doktrin keagamaan $^{45}$.

Inilah langkah pertama yang dilakukan Islam emansipatoris sebagai jalan menuju agenda selanjutnya. Kemudian setelah itu Islam emansipatoris merumuskan tiga hal dalam merumuskan Islam yang ingin diletakkan dalam tataran praktis diskursif. Pertama, memberikan pandangan baru tentang teks,

\footnotetext{
${ }^{42}$ Zaim Uchrowi. (1989). Refleksi Pembaharuan Pemikiran Islam: 70 Tahun Harun Nasution. Jakarta: Panitia Penerbit Buku dan Seminar 70 Tahun Harun Nasution dan Lembaga Studi Agama dan Fils. Halm. 122.

43 Tibbi, Bassam. (1988) The Crisis of Modern Islam: A preindustrial Culture in the ScientificTeknologikal Age. Slat Lake City: The University of Utah Press. Halm 77.

${ }^{44}$ Very Verdiansyah. (2004). Islam Emansipatoris: Menafsir Agama untuk Praksis Pembebasan.cet. I.Jakarta: P3M. Halm 89.

${ }^{45}$ Very Verdiansyah. (2004). ......., Halm 87.
} 
yakni melihat teks dari permasalahan kontekstual dan problem kemanusiaan, karena teks lahir dari situasi sosio-kultural masyarakat pada zamannya ${ }^{46}$. Kedua, menempatkan manusia sebagai subjek penafsiran keagamaan. Selama ini pemahaman agama berangkat dari teks yang kemudian diturunkan menjadi hukum dalam rangka memberi status hukum kepada realitas. Akibatnya teks menjadi kehilangan semangat transformatifnya. Ketiga, Islam emansipatoris fokus pada permasalahan manusia bukan pada perdebatan teologis, dalam artian bahwa persoalan agama dialihkan ke permasalahan praktis bukan permasalahan ritualistik, atau dari permasalahan teosentris menuju antroposentris. Dengan demikian, agama selain berperan sebagai ritual peribadatan, tapi agama juga berperan sebagai sarana pembebasan ${ }^{47}$.

Keempat : Islam Kultural. Islam kultural merupakan gerakan pemikiran keislaman yang berkembang di Indonesia dengan pendekatan ilmu sosial, seperti antropologi, ilmu budaya, sosiologi, dan sejarah. Sebagaimana pengertian kebudayaan tersebut sebagai sebuah hasil karya budi daya manusia. Ini merupakan pengertian yang sangat umum, namun jika kita melihat dari bentuk kebudayaan yang dihasilkan yakni dalam dua bentuk, intelektual (pemikiran kefilsafatan, seni sastra), dan benda (benda-benda bersejarah). Istilah kultural berasal dari kata culture yang berarti kesopanan, kebudayaan, dan pemeliharaan $^{48}$ berdasarkan perspektif kebudayaan untuk memahami Islam. Islam kultural dapat dimaknai sebagai sebuah pemikiran yang dibangun.

Kelima : Islam Liberal. Istilah Islam liberal sejatinya didasarkan atau mengacu pada kesadaran akan pentingnya sebuah gerakan memikirkan dan menafsirkan Islam secara kontekstual, kritis, dinamis, progresif, dan modern ${ }^{49}$. Maka dalam hal ini dapat dikatakan bahwa Islam liberal merupakan kelompok Islam yang mencoba melakukan ijtihad secara bebas dalam arti tidak lagi mau dipenjara dalam sistem pemahaman keislaman yang sifatnya diwarisi dari Islam klasik saja, atau kelompok Islam yang mencoba lepas dari penjara tradisi dalam

\footnotetext{
${ }^{46}$ Ayzumardi azra. (1999b). Islam Reformis; Dinamika Intelektual dan Gerakan. cet. I. Jakarta: PT Grapindo Persada. Halm 126.

${ }^{47}$ Very Verdiansyah. (2004). Islam Emansipatoris: Menafsir Agama untuk Praksis Pembebasan.cet. I.Jakarta: P3M. Halm 90.

${ }^{48}$ Hanafi,Hasan. (2003). Aku Bagian Dari Fundamentalsime Islam. terj., Kamran As'ad Irsady Mufliha Wijayanti. cet. I. Yogyakarta: Islamika.

${ }^{49}$ Hanafi,Hasan. (2003)......., Halm 97.
} 
memahami agama dan melihat realitas kehidupan. Atau kelompok Islam yang mengusung kebebasan dalam melakukan ijtihad dalam artian tidak dimonopoli oleh kaum tua atau ulama semata ${ }^{50}$.

Inti dari Islam liberal adalah meramu Islam berdasarkan realitas dan kondisi globalitas zaman yang empirik, dengan cara melakukan reinterpretasi Islam agar sesuai dengan kondisi zaman yang ada, mereka berangkat dari realitas baru kepada teks, namun teks agama tidak dijadikan sebagai legitimasi atas realitas Istilah yang dipakai oleh Charles Kurzman dalam bukunya Liberal Islam; a Source Book $^{51}$. Dalam buku ini termuat beberapa tokoh Islam kontemporer yang dilihat sebagai pemikir liberal, progresif, independen, kritis, dan modern. Sebelumnya terdapat buku yang ditulis oleh Leonard Binder, Islamic Liberalizm. Dan buku Albert Hourani, Arabic Thought in The yang ada, melainkan yang ingin dilakukan dengan cara tersebut adalah sebuah pemahaman yang lebih aktual dan progresif sehingga agama menjadi tidak kering dan mandul, atau agama tidak menjadi penghalang bagi pluralisme, agama tidak lagi menjadi alasan untuk memarjinalkan perempuan, agama tidak lagi menjadi penghalang bagi demokrasi, agama tidak lagi menjadi penjara bagi kebebasan dalam mengekspresikan keyakinan dan peribadatan masyarakat ${ }^{52}$.

Di era millennium ini muncul tokoh- tokoh muda Islam yang terhimpun dari berbagai golongan dan profesi, yakni dari kalangan NU, Paramadina, Aktivis Jurnalis, IAIN Jakarta, di samping juga golongan tua di era tahun 1980an yang berpendidikan luar negeri terutama di Amerika. Mereka terhimpun dalam satu komunitas Islam yang disebut Islam Liberal Indonesia. Kelompok Islam liberal boleh dipandang sebagai sintesis dari demokrasi dan Islam. Mereka menafsirkan sejarah dan doktrin Islam menjadi paralel dengan prinsip-prinsip demokrasi yang berkembang di Indonesia, dan pluralisme kebudayaan modern ${ }^{53}$.

Keenam: Islam Modernis. Mengenai definisi Islam modernis, para peneliti memberikan pandangan yang berbeda namun substansinya sama, yakni

\footnotetext{
${ }^{50}$ Very Verdiansyah. (2004). Islam Emansipatoris: Menafsir Agama untuk Praksis Pembebasan.cet. I.Jakarta: P3M. Halm 98.

${ }^{51}$ Echols, John M. dan Hassan Shadily. (1979). Kamus Inggris Indonesia.cet. VII. Jakarta: Gramedia. Halm 65.

${ }^{52}$ Tibbi, Bassam. (1988) The Crisis of Modern Islam: A preindustrial Culture in the Scientific-

Teknologikal Age. Slat Lake City: The University of Utah Press. Halm 88.

53 Tibbi, Bassam. (1988),......, Halm 99.
} 
ingin melakukan perubahan dalam pola pikir dan cara pandang terhadap Islam dengan melakukan reinterpretasi secara kontekstual. melihat modernisme sebagai upaya untuk menyesuaikan atau mengharmoniskan antara agama dan pengaruh modernitas serta westernisasi yang sedang berlangsung di dunia Islam. Usaha tersebut dilakukan dengan cara menafsirkan dasar-dasar doktrin Islam agar relevan dengan semangat zaman. Sementara itu, yang melihat gerakan modernis Islam sebagai upaya untuk melakukan akulturasi budaya, yakni dengan melakukan integrasi sains dan teknologi modern ke dalam Islam sambil melakukan preventifikasi atas konsekuensi negatif yang akan muncul dari penerapannya $^{54}$. Sedangkan Mukti Ali (1998) melihat modernisme Islam sebagai gerakan yang berupaya melakukan purifikasi agama dan kebebasan berpikir. Maka Islam modernis adalah gerakan ke arah puritanisasi untuk mengajak umat Islam kembali kepada al- Qur'an dan Sunnah serta mengajak untuk diberikannya ruang bagi akar untuk mengeksplorasi Islam sepanjang eksplorasi tersebut tidak bertentangan dengan Qur'an dan Sunnah ${ }^{55}$.

Dari definisi di atas, maka kita dapat memberikan identitas kepada kelompok Islam modernis sebagai: pertama, kelompok yang menganjurkan ijtihad terutama mengenai persoalan muamalah atau sosial kemasyarakatan. Dalam upaya ini mereka cenderung bersifat inklusif dalam melakukan penafsiran, baik bersumber dari peradaban lain dengan cara akulturasi, maupun dengan cara adaptif. Kedua, dengan penekanan pada ijtihad, maka sudah pasti mereka tidak membenarkan sikap jumud dan taklid buta, sebab yang demikian tidak mencerminkan penggunaan akal, melainkan sikap dogmatis belaka. Pelabelan di atas pada kelompok modernis Islam dapat dilihat pada pandangan Fazlur Rahman (Islam), A. Mukti Ali (Islam dan modernisme), dan Deliar Noer $\left(\right.$ Gerakan Modern Islam) ${ }^{56}$.

Ketujuh: Islam Pluralis. Pluralisme adalah paham kemajemukan atau paham kebhinekaan yang berorientasi pada kemajemukan yang memiliki berbagai penerapan yang berbeda dalam filsafat, agama, moral, hukum, dan

54 Tibbi, Bassam. (1988) The Crisis of Modern Islam: A preindustrial Culture in the ScientificTeknologikal Age. Slat Lake City: The University of Utah Press. Halm 101.

55. — (1995). Islam Ditinjau dari Berbagai Aspek. Jilid I.cet. 5.Jakarta: UI Press. Halm. 44

56 . Fachry Ali dan Bahtiar Efendy. (1986). Merambah Jalan Baru Islam: Rekonstruksi Pemikiran Islam Indonesia Masa Orde Baru.Bandung: Mizan. Halm 99. 
politik yang mana batas kolektifnya ialah pengakuan atas kemajemukan di depan ketunggalan $^{57}$. Artinya, dalam eksistensi segala sesuatu, baik dalam ilmu pengetahuan, kepercayaan, ekonomi, politik, budaya, dan agama adalah hal yang bersifat mutlak sebagai hukum kehidupan. Jika itu mutlak, maka tidak ada yang berhak untuk diunggulkan atau didiskriminasikan satu dari yang lain, melainkan harus sejajar ${ }^{58}$.

Di Indonesia isu pluralisme agama mulai marak digulirkan oleh umat Islam. gerakan ini marak digulirkan mengingat sering terjadinya kekerasan dan perang antarumat beragama, seperti kekerasan antar Islam dan Kristen di Ambon, pengikut Ahmadiyah dan sebagainya. Ide pluralisme digulirkan dalam rangka menciptakan kehidupan beragama yang kondusif dan harmonis di Indonesia. Secara yuridis, kebebasan beragama memang dibenarkan dalam undang- undang, bahkan jika dilihat dari sila pertama Pancasila yang memakai bahasa Tuhan, ini mengindikasikan pluralitas agama di Indonesia ${ }^{59}$.

Atas dasar kondisi dan legitimasi undang-undang tersebut, maka gerakan harmonisasi antarumat beragama digalakkan oleh pemikir Islam Indonesia, seperti Nurcholis Madjid dengan karyanya seperti Pintu-pintu Menuju Tuhan, Alwi Shihab dengan idenya tentang Islam Inklusif, dan masih banyak yang lainnya ${ }^{60}$.

Pengertian konsep pluralisme kedalam empat bentuk; pertama, pluralisme tidak serta merta menunjuk pada adanya kemajemukan, melainkan yang dimaksud adalah keterlibatan aktif terhadap kenyataan kemajemukan tersebut. Dari sini pluralisme dimaknai sebagai setiap pemeluk agama dituntut untuk bukan saja mengakui keberadaan dan hak agama lain, tetapi terlibat dalam usaha memahami perbedaan dan persamaan agar tercapai kerukunan dalam keragaman $^{61}$. Kedua, pluralisme harus dibedakan dengan kosmopolitanisme.

\footnotetext{
${ }^{57}$ Fachry Ali dan Bahtiar Efendy. (1986),....., Halm 77.

58 . Zaim Uchrowi. (1989). Refleksi Pembaharuan Pemikiran Islam: 70 Tahun Harun Nasution.Jakarta: Panitia Penerbit Buku dan Seminar 70 Tahun Harun Nasution dan Lembaga Studi Agama dan Fils. Halm. 125.

${ }^{59}$ Zaim Uchrowi. (1989). Refleksi Pembaharuan Pemikiran Islam: 70 Tahun Harun Nasution. ..... Halm 130.

${ }^{60}$ Syari'ati,Ali. (1995). Islam Mazhab Pemikiran dan Aksi. terj., M. S. Nasrulloh dan Afip Muhammad. Halm 56.

${ }^{61}$ Al-Bana, Gamal.(2006). Pluralitas dalam Masyarakat Islam. terj., Tim Mata Air Publishing. Jakarta: Mata Air Publishing. Halm 78.
} 
Sebab kosmopolitanisme belum tentu mengarah pada interaksi yang baik antara perbedaan yang ada, walaupun semua masyarakat yang tinggal dalam satu wilayah atau kota saling bertemu setiap saat. Ketiga, konsep pluralisme tidak dapat disamakan dengan relativisme. Relativisme berpandangan bahwa hal-hal yang berkaitan dengan kebenaran dan nilai ditentukan oleh pandangan hidup serta kerangka berpikir seseorang atau masyarakat. Keempat, pluralisme bukan sinkretisme, yakni menciptakan agama baru dengan mengambil ajaran atau unsur tertentu dari agama-agama yang ada dan diintegrasikan ke dalam agama baru tersebut ${ }^{62}$.

Jika ditilik dari tujuannya menciptakan harmoni antarumat beragama, maka Islam pluralisme boleh dikatakan sebuah gerakan yang harus didukung, sebab agama merupakan hal yang rawan konflik. Oleh sebab itu, perlu adanya sebuah pemahaman yang lebih substantif terhadap agama itu sendiri. Islam pluralis sejatinya harus ditempatkan pada posisi tersebut, sehingga dengan kelahirannya tidak mendatangkan konflik baru dalam agama ${ }^{63}$. Hal ini perlu disadari oleh para perintis gerakan Islam pluralis, sebab apa bedanya jika orang yang tidak paham agama dan bertengkar antaragama dengan orang yang paham agama namun bertengkar pula dengan kepahamannya tersebut ${ }^{64}$. Maka, Islam pluralis harus kembali kepada jalur perdamaian dengan tidak terlalu mengotakatikkan doktrin fundamental agama, dalam hal ini adalah Islam, sebab jika demikian maka Islam pluralis sebetulnya hadir untuk membuat konflik di dalam konflik $^{65}$.

Kedelapan: Islam Radikal. Secara sosiologis bisa diterangkan bahwa radikalisme kerap kali muncul bila terjadi banyak kontradiksi dalam orde sosial yang ada. Bila masyarakat yang mengalami anatomi atau kesenjangan antara nilai-nilai dengan pengalaman, dan masyarakat tidak mempunyai daya lagi untuk mengatasi kesenjangan itu, maka radikalisme dapat muncul ke permukaan. Dengan kata lain, akan timbul proses radikalisme dalam lapisan-

\footnotetext{
62. Arkoun,Mohamed (ed). (1999). Membongkar Wacana Hegemoni dalam Islam dan Postmodernis. terj. Jaohari dkk. cet. I. Surabaya: al- Fikri. Halm. 45.

${ }^{63}$ Arkoun,Mohamed (ed). (1999), ......., Halm 78.

${ }^{64}$. Amstrong, Karen. (2001). Berperang Demi Tuhan.terj., Sartio Wahono dkk. Bandung: Mizan. Halm 45.

65. Hanafi,Hasan. (2003). Aku Bagian Dari Fundamentalsime Islam. terj., Kamran As'ad Irsady Mufliha Wijayanti. cet. I. Yogyakarta: Islamika. Halm. 89.
} 
lapisan masyarakat, terutama di kalangan anak muda ${ }^{66}$.

Berpijak pada tataran sosiologis di atas, radikalisme dapat dicirikan dan ditandai oleh tiga kecenderungan umum. Pertama, radikalisme merupakan respon terhadap kondisi yang sedang berlangsung. Biasanya respon tersebut muncul dalam bentuk evaluasi penolakan atau bahkan perlawanan. Masalahmasalah yang ditolak dapat berupa asumsi, ide, lembaga atau nilai-nilai yang dapat dipandang bertanggung jawab terhadap kondisi yang ditolak ${ }^{67}$. Kedua, radikalisme tidak berhenti pada upaya penolakan, melainkan terus berupaya mengganti tatanan-tatanan tersebut dengan suatu bentuk tatanan yang lain. Ciri ini menunjukkan bahwa di dalam radikalisme terkadang suatu program atau pandangan dunia (worl view) tersendiri. Kaum radikal berupaya kuat untuk menjadikan tatanan tersebut menjadi ganti dari tatanan yang sudah ada. Ketiga, kuatnya keyakinan kaum radikalis terhadap kebenaran yang mereka bawa. Sikap ini pada saat yang sama dibarengi dengan penafian kebenaran dengan sistem lain yang akan diganti. Dalam gerakan sosial, keyakinan tentang kebenaran program atau filosofi sering dikombinasikan dengan cara-cara pencapaian yang mengatasnamakan nilai- nilai ideal, seperti kerakyatan atau kemanusiaan.Akan tetapi kuatnya keyakinan ini dapat mengakibatkan munculnya sikap emosional yang menjurus pada kekerasan ${ }^{68}$.

Kesembilan : Islam Rasional. Islam Rasional berarti Islam yang diproses melalui akal pikiran manusia dalam membentuk keyakinannya terhadap Islam. Sebagaimana pengertian rational (bahasa Inggris) yang berarti masuk akal atau logis ${ }^{69}$ atau jika dikembangkan menjadi pemikiran, persepsi atau pandangan yang berlandaskan pada akal yang sistematis dan logis. Namun perlu ditegaskan di sini, bahwa penggunaan akal dalam konteks Islam tidak dimaksudkan sebagai sebuah tolok ukur merumuskan kebenaran atau menjadi panduan hidup sebagaimana di Barat yang bersifat antroposentris, yang menitikberatkan kebebasan berpikir sebagai tolok ukur kebenaran, apa yang ada dalam pikiran

\footnotetext{
66 . Hanafi, Hasan. (2003), .... , Halm 77.

67 . Arkoun,Mohamed (ed). (1999). Membongkar Wacana Hegemoni dalam Islam dan Postmodernis. terj. Jaohari dkk. cet. I. Surabaya: al- Fikri. Halm. 66.

${ }^{68}$ Arkoun,Mohamed (ed). (1999). Membongkar Wacana Hegemoni dalam Islam dan Postmodernis. terj.,....Halm 70.

69 . Echols, John M. dan Hassan Shadily. (1979). Kamus Inggris Indonesia.cet.VII. Jakarta: Gramedia. Halm. 89.
} 
mesti bersesuaian dengan apa yang ada dalam tataran realitas empirik, dan jika realitas yang empirik tidak bersesuaian dengan akal, maka realitas tersebut diabaikan $^{70}$.

Dalam konteks Indonesia tokoh yang dianggap rasional adalah Nurcholis Madjid, Harun Nasution, Abdurrahman Wahid, Ahmad Wahib, Amin Rais, dan masih banyak yang lainnya. Bagaimana paradigma Islam yang dikembangkan Islam rasional? Inilah yang akan dibahas dalam tulisan ini, terutama pandangan harun Nasution. Sedangkan yang lainnya telah dilabelkan dalam kelompok pemikiran yang lain, seperti Nurcholis Madjid, Djohan Effendi, Ahmad Wahib, dan Abdurrahman Wahid lebih dilihat sebagai tokoh Neo-Modernisme Islam oleh Greg Barton (1999), dengan sebutan Islam yang wajar atau Islam kultural (terutama Nurcholis Madjid dan Gus Dur) ${ }^{71}$. Harun Nasution (1919-1998) dikenal sebagai tokoh yang rasionalis, sehingga karya-karya yang dilahirkannya hampir tidak lepas dari pandangan beliau yang rasional tersebut, seperti, Islam Ditinjau dari Berbagai Aspek; Pembaharuan dalam Islam: Sejarah Pemikiran dan Gerakan; Teologi Islam Aliran-aliran Sejarah Analisa Perbandingan; Filsafat Agama; Falsafah dan Mistik dalam Islam; Akal dan Wahyu dalam Islam; Perkembangan Modern dalam Islam; Muhammad Abduh dan Teologi Rasional Mu'tazilah; dan Islam Rasional Gerakan dan Pemikiran Dengan sikapnya yang rasional itulah, maka Harun merupakan tokoh modernis yang dimiliki oleh umat Islam Indonesia ${ }^{72}$. Namun, perlu dari awal ditekankan bahwa akal dalam pandangan tidaklah bisa menghapus wahyu, wahyu tetap dianggap sebagai yang unggul dan mutlak benar, Akal hanya menginterpretasi teks wahyu sesuai dengan kebutuhan manusia $^{73}$.

Kesepuluh: Islam Revivalisme. Revivalisme Islam (kebangkitan kembali Islam) memiliki cakupan yang sangat luas, baik yang bersifat elegan (tanpa kekerasan) yang intisifikasinya lebih diarahkan pada penghayatan dan

\footnotetext{
70 . Echols, John M. dan Hassan Shadily. (1979). ..... , Halm 89.

71 . Fachry Ali dan Bahtiar Efendy. (1986). Merambah Jalan Baru Islam: Rekonstruksi Pemikiran Islam Indonesia Masa Orde Baru.Bandung: Mizan. Halm 105.

${ }^{72}$. Zaim Uchrowi. (1989). Refleksi Pembaharuan Pemikiran Islam: 70 Tahun Harun Nasution. ..... Halm 133.

73. Harun Nasution. (1986). Akal dan Wahyu dalam Islam. cet. II. Jakarta: UI- Press. Halm. 90.
} 
pengamalan Islam secara individual maupun kolektif atau berkelompok. Tujuannya hanya menghidupkan kembali Islam secara damai dalam kehidupan sehari-hari untuk membendung arus modernisasi yang mengarah pada terciptanya budaya vulgar dalam diri umat Islam. Di samping itu, gerakan revivalisme Islam juga bisa berbentuk radikal-militan, yang bernaung di bawah payung fundamentalisme Islam, yang bertujuan untuk menciptakan sistem sosial, budaya, politik, dan ekonomi yang bercirikan Islam $^{74}$.

Berbeda dengan pandangan di atas, bahwa revivalisme Islam dalam konteks Indonesia merupakan gerakan keislaman yang bertujuan untuk mengembalikan Islam pada ajaran yang murni. Argumentasi mereka dalam hal ini adalah bahwa umat Islam mengalami kemunduran di era modern yang berhadapan dengan Barat, dikarenakan Islam yang diamalkan telah mengalami distorsi, sudah bercampur dengan bid'ah, khurafat, tahayul, kepercayaan dan tradisi lokal, serta pemikiran dan ideologi sosial modern Barat. Karena itulah Islam harus dimurnikan kembali. Dalam upaya pelaksanaan puritanisasi Islam tersebut, khususnya dalam masalah- masalah yang berkenaan dengan hukum ${ }^{75}$.

Kesebelas: Islam Spiritualis-Sufistik. Pertama, Islam spiritualis-sufistik dalam bentuk gagasan pemikiran. Hal ini terkait dengan gagasan untuk membangun perdamaian antarumat beragama di Indonesia agar tidak terjadi konflik atas nama Tuhan. Islam sebagai agama yang mayoritas pengikutnya di Indonesia harus menjadi kekuatan untuk menebarkan perdamaian, sebab Islam memiliki perangkap yang kuat dan banyak secara doktrinal dan historis. jika umat Islam mengakui keesaan Tuhan dan kekekalan-Nya, maka sebetulnya sudah mengakui pluralitas di luar Tuhan, bahwa yang Tunggal hanyalah Allah dan di luar Allah adalah plural. Jika ini tidak diyakini maka secara tidak sadar umat Islam telah menyekutukan Allah ${ }^{76}$.

Kedua, gerakan Islam spiritualis-sufistik dalam tataran praktik dan pengamalan. Ini merupakan paham yang mempraktikkan unsur batiniah atau esoterik dalam Islam yang dapat diperoleh melalui peran aktif pada kelompok-

\footnotetext{
74 Azyumardi Azra. (1999b). Islam Reformis; Dinamika Intelektual dan Gerakan. cet. I. Jakarta: PT Grapindo Persada. Halm 90.

75 . Azyumardi Azra. (1999b). Islam Reformis; Dinamika Intelektual dan Gerakan. cet. I. ....., Halm 102.

76 Al-Bana, Pluralitas dalam Masyarakat Islam. terj., Tim Mata Air Publishing. Jakarta: Mata Air Publishing...... Halm 90.
} 
kelompok eksklusif spiritualis, tasawuf atau tarekat. Kelompok ini tidak mau terlibat atau tidak peduli dengan permasalahan sosial, baik ekonomi, politik, dan sebagainya, langkah yang diambil oleh kaum revivalis adalah penerapan dan pengembangan ijtihad, yang terpenting adalah bagaimana mendapatkan kesucian batin dan dekat dengan Tuhan terkadang menimbulkan disorientasi dan dislokasi psikologis pada masyarakat tertentu, di samping juga disebabkan oleh ketidakpuasan terhadap bentuk agama yang dikembangkan oleh ulama atau organisasi keagamaan yang lebih bersifat normatif-ritualistik semata atau eksoteris ${ }^{77}$.

Islam spiritualis-sufistik dalam tataran pemikiran para intelektual Islam Indonesia bertujuan untuk mendamaikan dan menciptakan kehidupan yang harmonis antarumat beragama ${ }^{78}$. Sebab pluralitas merupakan kepastian yang tidak bisa dihindarkan selama kita masih berstatus hamba dan sebagai mahluk. Dengan ide pluralisme atau kesatuan teologis diharapkan akan tercapai kehidupan yang toleran, egalitarian, dan harmonis di Indonesia yang pluralistis ini. Di samping itu, Islam spiritualis-sufistik dalam tataran praktis adalah untuk mengembalikan Tuhan dalam diri kehidupan masyarakat yang modern yang berada dalam hegemoni kebutuhan material, sehingga nilai-nilai transendental menjadi terabaikan, dan ini merupakan implikasi dari munculnya isme-isme Barat yang bernuansa sekuler. Maka Islam eso- ritualis-sufistik hadir untuk mengembalikan Tuhan ke dalam diri ${ }^{79}$.

Keduabelas: Islam Transformatif. Islam transformatif lahir untuk mengubah, membentuk, dan untuk Kelompok ini muncul di Indonesia lebih disebabkan oleh proses modernisasi dan globalisasi yang selanjutnya menjadikan Islam yang berfungsi dalam segala aspek kehidupan. Hal ini sesuai dengan makna dari kata transformation (bahasa Inggris) yang berarti perubahan atau menjadi ${ }^{80}$. Dari definisi ini maka secara umum, bahwa Islam transformatif mengemban tugas kedepan sebagai tujuan: 1) pemikiran Islam yang bertujuan

\footnotetext{
${ }^{77}$ Al-Bana, Pluralitas dalam Masyarakat Islam. Ter. ..... Halm 89.

${ }^{78}$. Al-Bana, Pluralitas dalam Masyarakat Islam. Ter. .....Halm 90.

79 Barr, James.(1996). Fundamentalisme. terj., Stephan Suleman. cet. 2. Jakarta: BPK Gunung Mulya. Halm 99.

80. Echols, John M. dan Hassan Shadily. (1979). Kamus Inggris Indonesia.cet.VII. Jakarta: Gramedia. Halm. 89.
} 
mengaktualisasikan Islam yang rahmatan lil alamin. 2) Islam transformatif bertujuan untuk menciptakan kehidupan yang integral dan holistik dalam kehidupan, yakni pemaduan antara kesalehan vertikal yang kemudian terwujud dalam kesalehan sosial- horizontal. Dengan kata lain, aktualisasi nilai ritual ibadah yang dikerjakan ke dalam kehidupan sosial dalam bentuk cinta, kasih sayang, toleran, dan egalitarian terhadap sesama manusia, bahkan mungkin terhadap lingkungan alam. 3) bertujuan untuk mengembangkan Islam yang aktual pada kondisi zaman yang dihadapi ${ }^{81}$.

Salah satu tokoh pemikir Islam Indonesia yang begitu populer dan memiliki ide-ide transformatif yang luar biasa, yakni Kuntowijoyo. Ide transformasi masyarakat Kuntowijoyo dilakukan dengan pendekatan historis, sehingga pemikiran Kuntowijoyo lebih bersifat metodologis ketimbang substantif. Terkait dengan formulasi sistem dan keilmuan Islam yang rasional dan empiris tersebut, menawarkan lima cara reaktualisasi ajaran Islam sebagai bentuk kebangkitan dan respons umat ${ }^{82}$.

Pada penafsiran individual ketika memahami ketentuan- ketentuan tertentu di dalam al-Qur'an. Kedua, mengubah cara berpikir subjektif menjadi cara berpikir objektif. Ketiga, mengubah Islam yang normatif menjadi teoretis. Keempat, mengubah pemahaman yang a-historis menjadi pemahaman yang historis. Kelima, merumuskan formulasi wahyu yang bersifat umum menjadi formulasi yang bersifat spesifik dan empirik. Dengan diaktualisasikannya kelima cara tersebut Kuntowijoyo optimis bahwa umat Islam Indonesia akan mampu menjawab tantangan zaman yang dihadapi ${ }^{83}$.

Ketigabelas: Neo-Modernisme Islam. Gerakan Neo-Modernisme Islam untuk pertama kali ditegaskan oleh Fazlur Rahman. Baginya, Neo-Modernisme merupakan sintesa dari rasionalitas kaum modernis dengan tradisi klasik Islam. Sebelumnya Rahman memaparkan bahwa sejarah gerakan Islam pada dua abad terakhir terbagi ke dalam empat bentuk: Pertama, gerakan revivalis di akhir abad

\footnotetext{
81. Arkoun,Mohamed (ed). (1999). Membongkar Wacana Hegemoni dalam Islam dan Postmodernis. terj. Jaohari dkk. cet. I. Surabaya: al- Fikri. Halm 67.

82. Echols, John M. dan Hassan Shadily. (1979). Kamus Inggris Indonesia.cet.VII. Jakarta: Gramedia. Halm. 93.

83. Hanafi,Hasan. (2003). Aku Bagian Dari Fundamentalsime Islam. terj., Kamran As'ad Irsady Mufliha Wijayanti. cet. I. Yogyakarta: Islamika. Halm. 89.
} 
ke- 18 dan awal abad ke-19. Kedua, gerakan modernis. Ketiga, Neo-revivalis yang modern namun agak reaksionis. Keempat, Neo- modernis, yakni yang diusung oleh Fazlur Rahman sendiri. ${ }^{84}$

Neo-modernsme Islam ini untuk pertama kali digagas di Indonesia pada sosok seorang Nurcholis Madjid dengan Pembaharuan Pemikiran Islam dan Masalah Integrasi Umat. Makalah ini kemudian disebarluaskan oleh media masa, baik cetak maupun tulis tanpa sepengetahuan Cak Nur Tokoh-tokoh yang tergolong dalam kelompok neo-modernis ini adalah Nurcholis Madjid, Djohan Efendi, Abdur Rahman Wahid, Ahmad Wahid, Jalaluddin Rahmat, Amin Rais, dan lain-lain ${ }^{85}$

Neo-modernisme Islam Indonesia juga merupakan sebuah kontinuitas atau merupakan kombinasi dari dua unsur penting tradisi pemikiran dan gerakan Islam di Indonesia, yakni modernisme dan tradisionalisme. Neo-modernisme mencoba mengkombinasikan kedua kelompok tersebut. Namun, tetap memiliki perbedaan dengan modernisme sebelumnya (Muhammadiyah dan Persatuan Islam), yakni Neo-modernisme lebih berani untuk menerima dan mengakomodasi ide-ide yang paling maju dan progresif, meskipun itu datang dari budaya sekulerisme Barat (inilah sikap inklusif yang ditampilkan), di samping itu juga menerima pandangan kaum tradisionalis ${ }^{86}$. Namun, dalam rangka menerima gagasan modernisme dan tradisionalisme tersebut, kelompok neo- modernisme tetap melakukan klasifikasi dan interpretasi sebagai sikap selektif bukan reseptif, dengan maksud akan melahirkan ide mengembangkan pembaruan pemikiran dalam Islam sekitar tahun 70- an pada sebuah seminar yang diisi oleh Nurcholis Madjid yang menyampaikan makalah berjudul Keharusan sebuah sintesis baru yang siap untuk dipakai dalam upaya pembaharuan, hal ini terlihat dengan penguasaan pada ilmu pengetahuan klasik Islam dan perkembangan keilmuan modern Barat $^{87}$.

\footnotetext{
84. Rahman, Fazlur. (1982). Islam. Chicago: The University of Chicago Press.). Halm 78.

85. Arkoun,Mohamed (ed). (1999). Membongkar Wacana Hegemoni dalam Islam dan Postmodernis. terj. Jaohari dkk. cet. I. Surabaya: al- Fikri. Halm 67.

86 . Syari’ati,Ali. (1995). Islam Mazhab Pemikiran dan Aksi. terj., M. S. Nasrulloh dan Afip Muhammad.

${ }^{87}$ Jalaluddin Rahmat. (1998). Islam Alternatif: Ceramah-Ceramah di Kampus. cet. 2. Bandung: Ghanesa.
} 


\section{Kesimpulan}

Keragaman keberislaman masyarakat Islam Indonesia membuktikan bahwa pemahaman dan pengamalan terhadap agama Islam di kalangan masyarakat menunjukkan multikulturalisme yang sangat kompleks. Artinya, agama yang dipahami oleh masyarakat Islam Indonesia jelas memiliki ciri dan karakter tersendiri dibanding dengan cara pemahaman masyarakat Timur Tengah, terutama Masyarakat Jazirah Arab tentang Islam itu sendiri. Keragaman masyarakat Islam Indonesia menunjukkan betapa indahnya khazanah kebhinekaan Indonesia jika diramu dengan semangat keagamaan yang toleran, moderat akan membentuk karakter bangsa Indonesia yang tercermin pada silasila Pancasila yang secara substantif sangat relevan dengan ajaran-ajaran Islam. 


\section{Daftar Pustaka}

Azyumardi Azra. (1996). Pergolakan Politik Islam; Dari

Fundamentalisme,Modernisme hingga Posmodernisme. cet. I. Jakarta: Paramadina.

(1999a). Konteks Berteologi di Indonesia: Pengalaman Islam. cet. I.Jakarta: Paramadina.

1999b). Islam Reformis; Dinamika Intelektual dan Gerakan. cet. I. Jakarta: PT Grapindo Persada.

Al-Bana, Gamal.(2006). Pluralitas dalam Masyarakat Islam. terj., Tim Mata Air Publishing. Jakarta: Mata Air Publishing.

Arkoun,Mohamed (ed). (1999). Membongkar Wacana Hegemoni dalam Islam dan Postmodernis. terj. Jaohari dkk. cet. I. Surabaya: al- Fikri.

(2001). Islam Kontemporer Menuju Dialog Antaragama. terj. Ruslani. cet. I. Yogyakarta: Pustaka Pelajar.

Amstrong, Karen. (2001). Berperang Demi Tuhan.terj., Sartio Wahono dkk. Bandung: Mizan.

(2003). Islam Sejarah Singkat. terj., Fungky Kusnaendy Timur. Yogyakarta: Jendela.

Barr, James.(1996). Fundamentalisme. terj., Stephan Suleman. cet. 2. Jakarta: BPK Gunung Mulya.

Barton, Greg. (1999). Gagasan Islam Liberal Di Indonesia: Pemikiran NeoModernisme Nurcholis Madjid, Djohan Effendi, Ahmad Wahib, dan Abdurrahman Wahid. terj., Nanang Tahqiq. Jakarta: UIN Press.

Echols, John M. dan Hassan Shadily. (1979). Kamus Inggris Indonesia.cet.

VII. Jakarta: Gramedia.

Fachry Ali. (1996). Golongan Agama dan Etika Kekuasaan: Keharusan Demokratisasi dalam Islam Indonesia. cet. I. Surabaya: Risalah Gusti.

Fachry Ali dan Bahtiar Efendy. (1986). Merambah Jalan Baru Islam: Rekonstruksi Pemikiran Islam Indonesia Masa Orde Baru. Bandung: Mizan.

Golpeigani, A. R. (2005). Kebenaran Itu Banyak: Menggugat Pluralisme. Terj., Muhammad Musa. cet. I.Jakarta: AL-HUDA.

Hanafi,Hasan. (2003). Aku Bagian Dari Fundamentalsime Islam. terj., Kamran As'ad Irsady Mufliha Wijayanti. cet. I. Yogyakarta: Islamika. 
Harun Nasution. (1986). Akal dan Wahyu dalam Islam. cet. II. Jakarta: UIPress.

(1995). Islam Ditinjau dari Berbagai Aspek. Jilid I.cet. 5.Jakarta: UI Press.

Jalaluddin Rahmat. (1998). Islam Alternatif: Ceramah-Ceramah di Kampus. cet. 2. Bandung: Ghanesa.

Lawrence, Bruce B. (2004). Islam Tidak Tunggal: Melepaskan Islam Dari Kekerasan.terj., Harimukti Bagus Oka. cet. II. Jakarta: Serambi.

Rahman, Fazlur. (1982). Islam. Chicago: The University of Chicago Press.)

Syari’ati,Ali. (1995). Islam Mazhab Pemikiran dan Aksi. terj., M. S. Nasrulloh dan Afip Muhammad.

cet. II. Bandung: Mizan.

(1996). Tugas Cendikiawan Muslim terj., M. Amin Rais.cet. I.Jakarta:

PT Grafindo Persada.

Tibbi, Bassam. (1988) The Crisis of Modern Islam: A preindustrial Culture in the Scientific-Teknologikal Age. Slat Lake City: The University of Utah Press.

Very Verdiansyah. (2004). Islam Emansipatoris: Menafsir Agama untuk Praksis Pembebasan.cet. I.Jakarta: P3M.

Zaim Uchrowi. (1989). Refleksi Pembaharuan Pemikiran Islam: 70

Tahun Harun Nasution. Jakarta: Panitia Penerbit Buku dan Seminar 70 Tahun Harun Nasution dan Lembaga Studi Agama dan Fils 